\title{
PENTINGNYA PENGETAHUAN PERAWAT TENTANG PROSES KEPERAWATAN DALAM PEMBERIAN ASUHAN KEPERAWATAN DI RUMAH SAKIT
}

\author{
Hanita Grace Sagala hanitagrace10@gmail.com
}

\begin{abstract}
ABSTRAK
Kualitas pelayanan ditentukan oleh asuhan keperawatan. Pelaksanaan asuhan keperawatan menggunakan metode proses keperawatan untuk menyelesasikan masalah pasien, antara pasien, antara perawat dengan pasien berhubungan secara langsung dalam pengolahan asuhan keperawatan. Penerapan proses keperawatan dalam asuhan keperawatan untuk klien merupakan salah satu wujud tanggung jawab dan tanggung gugat perawat terhadap klien. Proses keperawatan merupakan cara yang sistematis yang dilakukan oleh perawat bersama dengan klien dalam menentukan asuhan keperawatan dengan melakukan pengkajian, merumuskan diagnose, merencanakan tindakan yang akan dilakukan, melaksanakan tindakan serta mengevaluasi hasil asuhan yang telah diberikan dengan berfokus pada klien. Tahapan proses keperawatan meliputi : tahap pengkajian, tahap diagnosa, tahap perencanaan, tahap pelaksanaan, tahap evaluasi.
\end{abstract}

Kata kunci : Proses keperawatan, manfaat proses keperawatan, asuhan keperawatan, tujuan proses keperawatan, pentingnya proses keperawatan di RS

\section{Latar Belakang}

Proses keperawatan adalah aktivitas yang mempunyai maksud yaitu praktik keperawatan yang dilakukan dengan cara yang sistematik. Selama melaksanakan proses keperawatan, perawat menggunakan dasar pengetahuan yang komprehensif untuk mengkaji status kesehatan klien, membuat penilaian yang bijaksana dan mendiagnosa, mengidentifikasi hasil akhir kesehatan klien dan merencanakan, menerapkan dan mengevaluasi tindakan keperawatan yang tepat guna mencapai hasil akhir tersebut (Dermawan, 2012).

Asuhan keperawatan yang bermutu dan dapat dicapai jika pelaksanaan asuhan keperawatan dipersepsikan sebagai suatu kehormatan yang dimiliki oleh para perawat dalam memperlihatkan haknya untuk memberikan asuhan yang manusiawi, aman, serta sesuai dengan 
standar dan etika profesi keperawatan yang berkesinambungan dan terdiri dari kegiatan pengkajian, perencanaan, implementasi rencana, dan evaluasi tindakan keperawatan yang telah diberikan.

Penerapan proses keperawatan dalam asuhan keperawatan untuk klien merupakan salah satu wujud tanggung jawab dan tanggung gugat perawat terhadap klien. Pada akhirnya, penerapan proses keperawatan ini akan meningkatkan kualitas layanan keperawatan kepada klien.

Proses keperawatan merupakan cara yang sistematis yang dilakukan oleh perawat bersama dengan klien dalam menentukan asuhan keperawatan dengan melakukan pengkajian, merumuskan diagnose, merencanakan tindakan yang akan dilakukan, melaksanakan tindakan serta mengevaluasi hasil asuhan yang telah diberikan dengan berfokus pada klien. Lalu kelima proses tersebut didokumentasikan oleh perawat pada sebuah catatan keperawatan.

Proses keperawatan adalah mikanisme kerja keperawatan yang diterapkan untuk meningkatkan derajat kesehatan pasien dan metode dalam suatu konsep diterapkan dalam bentuk proses keperawatan. hal ini disebut sebagai pendekatan problemsolving yang merupakan suatu modalitas pemecahan masalah yang didasari oleh metode ilmiah yaitu metode yang memerlukan ilmu, teknik dan keterampilan interversonal dan ditunjukan untuk memenuhi kebutuhan pasien.

Proses keperawatan sebagai alat bagi perawat untuk melaksanakan asuhan keperawatan yang dilakuakan pada pasien memiliki arti penting bagi kedua bela pihak yaitu perawat dan klien. Sebagai seorang perawat proses keperawatan dapat digunakan sebagai pedoman dalam pemecahan masalah klien, dapat menunjukan profesi yang memiliki propesionalitas, yang tinggi, serta dapat memberikan kebebeasan kepada klien untuk mendapatkan pelayanan yang cukup sesuai dengan kebutuhannya, sehingga dapat dirasakan manfaatnya baik dari perawat maupunipasien, manfaat tersebut antara lain dapat meningkatkan kemandirian bagi perawat dalam melaksanakan tugasnya karena didalam proses keperawatan, akan dapat meningkatkan kepercayaan diri perawat dalam melaksanakan tugas, karena klien akan merasakan kepuasaan setelah dilakukan asuhan keperwatan dengan pendekatan proses keperawata, akan dapat selalu meningkatkan kemampuan intelektual dan teknikal dalam tindakan keperawatan karena melalui proses keperawatan dituntut dapat memecahkan 
masalah yang baru sesuai dengan masalah yang dialami klien, sehingga ditimbul perasaan akan kepuasan kerja.

\section{TUJUAN}

Tujuan dibuatnya kajian ini adalah untuk menambah wawasan dan memberikan informasi tentang manfaat proses keperawatan bagi perawat dan pasien di RS agar meningkatkan mutu peelayanan kesehatan yang optimal dan terstruktur.

\section{METODE}

Jenis metode penelitian ini adalah dengan metode eksplorasi bebas dan juga pendekatan jurnal. Sumber data yang dimuat berupa pengumpulan bahas pustaka tentang manfaat proses keperawatan bagi pasien dan juga perawat dirumah sakit. Metode ini menggunakan beberapa cara dalam manfaat proses keperawatan itu sendiri memberikan kerangka dalam asuhan keperawatan yang dibutuhkan dalam asuhan keperawatan pada klien, keluarga, serta komunitas dan merupakan metode yang efesien dalam membuat keputusan klinik serta pemecahan maslah baik actual maupun pontesial dalam mempertahankan kesehatan.

\section{HASIL}

Dari hasil literasi yang saya baca saya menemukan bahwa proses keperawatan merupakan hal yang sangat penting dalam memberi asuhan keperawatan di Rumah Sakit.

Penerapan proses keperawatan dalam asuhan keperawatan untuk klien merupakan salah satu wujud tanggung jawab dan tanggung gugat perawat terhadap klien. Pada akhirnya, penerapan proses keperawatan ini akan meningkatkan kualitas layanan keperawatan kepada klien.

Dan disalah satu jurnal yang saya baca saya menemukan bahwa ada beberapa tujuan proses keperawatan. Tujuan proses keperawatan menurut Manurung (2011) adalah sebagai berikut:

a. Mempraktikkan metode pemecahan masalah dalam praktik keperawatan.

b. Menggunakan standar untuk praktik keperawatan.

c. Memperoleh metoda yang baku dan sesuai, rational dan sistematis dalam memberikan asuhan keperawatan pada pasien.

d. Memperoleh metoda yang dapat digunakan dalam segala situasi.

e. Memperoleh hasil asuhan keperawatan dengan kualitas tinggi.

\section{PEMBAHASAN}

Proses keperawatan adalah salah satu metoda efektif pemecahan masalah yang dilakukan perawat terhadap klien dengan pendekatan metodologi ilmiah. Asuhan keperawatan dapat 
dipertanggungjawabkan berdasarkan substansi ilmiah yaitu logis, sistimatis, dinamis dan terstruktur (Muhlisin, 2011). Proses keperawatan adalah suatu metode ilmiah yang sistematis dan terorganisir dalam memberikan asuhan keperawatan pada pasien yang berfokus pada respon individu terhadap gangguan kesehatan yang dialami (Manurung, 2011). Menurut Yura, proses keperawatan merupakan suatu pendekatan sistematik untuk mengenal masalah klien dan mencari alternatif pemecahannya dalam memenuhi kebutuhan klien yang merupakan pendekatan ilmiah dalam memperbaiki dan meningkatkankesehatan klien sampai tahap maksimal.

Tenaga perawat mempunyai peran penting dalam kualitas pelaayanan kesehatan di Rumah Sakit, karena pelayanan keperawatan yang diberikannya berdasarkan pendekatan bio-psiko-sosialspiritual merupakan pelayanan yang unik dan dilaksanakan selama 24 jam dan berkesinambungan, hal ini merupakan kelebihan tersendiri dibanding profesi kesehatan lainnya (DepKes RI, 2005)

\section{Seiring perkembangan}

keperawatan, berbagai penemuan dalam dunia keperawatan diperkenalkan, salah satunya adalah keperawatan. Tahun 1955, Hall memperkenalkan istilah proses keperawatan. Namun, hal ini baru sekedar istilah dan belum dilaksanakan. Delapan tahun kemudian, Wiedenbach memperkenalkan 3 langkah dalam proses keperawatan, yaitu : observasi, bantuan pertolongan, dan validasi.

Perkembangan terhadap proses keperawatan berlanjut pada tahun 1967, dimana Knowles menemukan istilah yang menjelaskan tentang discovery (penemuan), divide (membagi), decide (memutuskan), do (melakukan), dan discrimination (membedakan). Perkembangan proses keperawatan terus terjadi. Di tahun yang sama, fakultas keperawatan sebuah universitas katolik di Amerika memperkenalkan 4 tahap proses keperawatan, yaitu : pengkajian, perencanaan, intervensi, dan evaluasi. Pada tahun 1982, National Council of State Boards of Nursing menyempurnakan tahapan dari proses keperawatan menjadi 5 tahap, yaitu : pengkajian, diagnosis, perencanaan, implementasi, dan evaluasi. Lima tahapan ilmiah yang sampai saat ini digunakan sebagai langkah-langkah proses keperawatan.

Kualitas pelayanan ditentukan oleh asuhan keperawatan. Pelaksanaan asuhan keperawatan menggunakan metode proses keperawatan untuk menyelesasikan masalah pasien, antara pasien, antara perawat dengan pasien berhubungan secara langsung dalam pengolahan asuhan keperawatan (Muhlisin, 2008). 
menurut (Budiono dan Pertami, 2015) manfaat proses keperawatan sebagai seorang perawat yaitu:

1. Perawat akan memiliki rasa percaya diri, akan lebih percaya diri dalam memberikan asuhan keperawatan, karena semua perencanaan sudah sipersiapkan terlbih dahulu dengan baik dan tepat berdasarkan diagnose keperawatan yang ditunjang oleh data yang tepat.

2. Perawat akan memberikan peningkaatn kualitas asuhan keperawatan. Dengan meningkatnya kualitas asuhan keperawatan maka semua klien mengalami kesembuhan, dan ini tentunya memberikan rasa puas tersendiri bagi anda.

3. Pengembangan profesionalisme perawat.

4. Proses keperawatan terdokumentasi dengan baik, akan memudahkan tenaga kesehatan lainnya untuk memberikan pelayanan kesehatan yang tepat.

Sementara itu proses keperawatan juga bermanfaat bagi pasien yaitu:

1. Pasien akan ikut berpartisipasi dalam menentukan perencanaan keperawatan, dan akan meningkatkan kerja sama pasien dalam pelaksanaan tindakan keprawatan.

2. Proses keperawatan menjamin pasien akan mendapatkan asuhan keperawatan yang tepat jika proses keperawatan juga tepat.

3. Proses keperawatan mencegah terjadinya duplikai tindakan dan kekurangan tindakan.

4. Pasien akan mendapatkan kulaitas pelayanan asuhan keperawatan yang tepat.

- Komponen Dalam Proses Keperawatan

1. Tahap Pengkajian

Pada dasarnya tujuan pengkajian adalah mengumpulkan data objektif dan subjektif dari klien. Adapun data yang terkumpul mencakup klien, keluarga, masyarakat, lingkungan, atau kebudayaan. (Mc Farland \& mc Farlane, 1997)

Adapun hal-hal yang perlu diperhatikan selama pengkajian antara lain:

1. Memahami secara keseluruhan situasi yang sedang dihadapi oleh klien dengan cara memperhatikan kondisi fisik, psikologi, emosi, sosialkultural, dan spiritual yagn bisa mempengaruhi status kesehatannya.

2. Mengumpulkan semua informasi yang bersangkutan dengan masa 
lalu, saat ini bahkan bahkan sesuatu yang berpotensi menjadi masalah bagi klien guna membuat suatu database yang lengkap. Data yang terkumpul berasal dari perawat-klien selama berinteraksi dan sumber yang lain. (Gordon, $1987 ; 1994)$

3. Memahami bahwa klien adalah sumber informasi primer.

4. Sumber informasi sekunder meliputi anggota keluarga, orang yang berperan penting dan catatan kesehatan klien.

Metode pengumpulan data meliputi

- Melakukan interview/wawancara.

- Riwayat kesehatan/keperawatan

- Pemeriksaan fisik

- Mengumpulkan data penunjang hasil laboratorium dan diagnostik lain serta catatan kesehatan (rekam medik)

\section{Tahap Diagnosa Keperawatan}

Diagnosa keperawatan adalah menganalisis data subjektif dan objektif untuk membuat diagnosa keperawatan. Diagnosa keperawatan melibatkan proses berpikir kompleks tentang data yang dikumpulkan dari klien, keluarga, rekam medik, dan pemberi pelayanan kesehatan yang lain.
The North American Nursing Diagnosis Association (NANDA, 1992) mendefinisikan diagnosa keperawatan semacam keputusan klinik yang mencakup klien, keluarga, dan respon komunitas terhadap sesuatu yang berpotensi sebagai masalah kesehatan dalam proses kehidupan.

- Dalam membuat diagnosa keperawatan dibutuhkan ketrampilan klinik yang baik, mencakup proses diagnosa keperawatan dan perumusan dalam pembuatan pernyataan keperawatan.

- Proses diagnosa keperawatan dibagi menjadi kelompok interpretasi dan menjamin keakuratan diagnosa dari proses keperawatan itu sendiri. Perumusan pernyataan diagnosa keperawatan memiliki beberapa syarat yaitu mempunyai pengetahuan yang dapat membedakan antara sesuatu yang aktual, risiko, dan potensial dalam diagnosa keperawatan.

3.Tahap Perencanaan

- Merupakan suatu proses penyusunan berbagai intervensi keperawatan yang dibutuhkan untuk mencegah, menurunkan, atau mengurangi masalah-masalah klien. 
- Didalam tahap perencanaan terdapat kegiatan yakni penentuan prioritas diagnosis yang dapat di ukur dengan berdasarkan tingkat kegawatan atau mengancam jiwa (tinggi, sedang, dan rendah), berdasarkan kebutuhan Maslow (fisiologis, keamanan dan keselamatan, mencintai dan dicintai, kebutuhan harga diri, dan kebutuhan aktualisasi diri).

- Adapun tipe instruksi perawatan dalam rencana tindakan adalah sebagai berikut:

1. Tipe diagnostik

2. Tipe terapeautik

3. Tipe penyuluhan

4. Tipe rujukan

\section{Tahap Pelaksanaan}

- Komponen implementasi dari proses keperawatan mempunyai lima tahap, yaitu:

1. Mengkaji Ulang Klien

2. Menelaah dan Memodifikasi Rencana Asuhan yang Ada

3. Mengidentifikasi Area Bantuan

4. Mengimplementasikan Intervensi Keperawatan

5. Mengkomunikasikan Intervensi

5.Tahap Evaluasi

Evaluasi mengacu kepada penilaian, tahapan, dan perbaikan. Pada tahap ini perawat menemukan penyebab mengapa suatu proses keperawatan dapat berhasil atau gagal. (Alfaro-LeFevre, 1994) Perawat menemukan reaksi klien terhadap intervensi keperawatan yang telah diberikan dan menetapkan apa yang menjadi sasaran dari rencana keperawatan dapat diterima.Perencanaan merupakan dasar yang mendukung suatu evaluasi. Menetapkan kembali informasi baru yang diberikan kepada klien untuk mengganti atau menghapus diagnosa keperawatan, tujuan, atau intervensi keperawatan. Menentukan target dari suatu hasil yang ingin dicapai adalah keputusan bersama antara perawat dank lien (Yura \& Walsh, 1988) Evaluasi berfokus pada individu klien dan kelompok dari klien itu sendiri. Proses evaluasi memerlukan beberapa keterampilan dalam menetapkan rencana asuhan keperawatan., termasuk pengetahuan mengenai standar asuhan keperawatan, respon klien yang normal terhadap tindakan keperawatan, dan pengetahuan konsep teladan dari keperawatan.

\section{PENUTUP}

Proses keperawatan adalah aktifitas yang mempunyai maksud yaitu praktik keperawatan yang dilakukan secara sistematik. Selama melakukan proses keperawatan, perawat menggunakan dasar pengetahuan yang komprehensif untuk mengkaji status kesehatan klien, membuat 
penilaian yang bijaksana dan mendiagnosa, mengidentifikasi hasil akhir kesehatan klien dan merencanakan, menerapkan dan mengevaluasi tindakan keperawatan yang tepat guna mencapai hasil akhir tersebut. Proses keperawatan juga memiliki manfaat yaitu:

1. Menghasilkan praktik keperawatan yang profesional

2. Meningkatkan rasa solidaritas dan rasa kesatuan perawat

3. Mengembangkan keterampilan teknis dan intelektual perawat

4. Mengambarkan otonomi dan tanggung jawab perawat

5. Meningkatkan citra profesi keperawatan

6. Meningkatkan layanan mutu keperawatan

Proses keperawatan juga memiliki tujuan yaitu:

1. Menggunakan metode pemecahan masalah.

2. Menggunakan standar untuk praktik keperawatan.

3. Memperoleh metode yang baku dan sesuai, rasional, dan sistematis.

4. Memperoleh metode yang dapat dipakai dalam segala situasi.

5. Mempunyai hasil asuhan keperawatan yang berkualitas tinggi.

Komponen Dalam Proses Keperawatan:

1. Tahap Pengkajian
2. Tahap Diagnosa Keperawatan

3. Tahap Perencanaan

4. Tahap Pelaksanaan

5. Tahap Evaluasi

\section{REFERENSI}

Asmadi.2005. Konsep Dasar Keperawatan Jakarta : ECG

Aini, D. N. (2018). Hubungan Kualitas Pelayanan Keperawatan dengan Tingkat Kepuasan Pasien Rawat Inap di RSUD DR. H. SOEWONDO KENDAL. Jurnal Ners Widya Husada Semarang, 2.

Budiono, \& Pertami, S.B. (2016).

Konsep Dasar Keperawatan. Jakarta: Bumi Medika.

Bumulo.dkk, (2017). Pengaruh Manajemen Model Asuhan Keperawatan Profesional Tim Terhadap Kualitas Pelayanan Keperawatan Di Bangsal Pria Rsud Datoe Binangkang Kabupaten Bolaang Mongondow. E-journal Keperawatan.,Vol 5.,No.2.,Agustus 2017.

Hasbi, F. H. (2012). Analisis Hubungan Persepsi Pasien tentang Mutu Pelayanan dengan Pemanfaatan 
Ulang Pelayanan Rawat Jalan

Puskesmas Poncol Kota Semarang.

Jurnal Kesehatan Masyarakat

Universitas Diponegoro, 1.

Nurhidayah. (2014). Manajemen Model

Asuhan Keperawatan Profesional

Tim dalam Peningkatan Kepuasan

Pasien di RS. Jurnal Kesehatan

UIN Alauddin Makassar, 3, 410-

426.

Putri dkk. (2016). Faktor-faktor yang

berhubungan dengan

penduokumentasian Asuhan

Keperawatan di Rumah Sakit Jiwa.

Jurnal Keperawatan Universitas

Indonesia, vol 12 no. 2 Oktober

2016 (hal 131-142)

Rohmah. (2016). Proses Keperawatan: \

Teori \& Aplikasi. Yogyakarta: Ar-

Ruzz Media.

Simamora, R. H. (2019). Development of

Guidelines for Applying

appropriate Patient Identification to

Achieve Patient Safety Goal

INC2019 12th International

Nursing Conference. 2019.10455 -

455 (1 pages) UCI(KEPA) : I410-

ECN-0101-2019-512-001224337

Simamora. R. H. (2008) The correlation of ward chief's giving direction and and the performance of on-duty nurses at Jember dr. Subandi general hospital inpatient wards. jurnal Administrasi dan Kebijakan Kesehatan,

(https://fkm.unair.ac.id/jurnaladministr)

Wantika, R. (2015, September 26). Proses Keperawatan. Retrieved from Wordpress:

https://ruryuswantika.wordpress. $\underline{\text { com/ }}$

Diakses : 24 September 2020

Yeni, F. (2014). Pengaruh pelatihan proses keperawatan terhadap dokumentasi asuhan keperawatan di puskesmas kabupaten agam propinsi sumatera barat . Ners Jurnal Keperawatan , 20-23. 